\title{
Toward a critical pedagogy of crisis
}

\section{Saskia Eschenbacher}

Akkon University of Applied Human Sciences, Germany (saskia.eschenbacher@akkonhochschule.de)

\section{Ted Fleming}

Teachers College Columbia University, USA (ejf2129@tc.columbia.edu)

\begin{abstract}
Crises in our society - climate, covid-19 and mass migration - seem to define not only the experience of learning but also the experience of living and even surviving that in turn have implications for adult learning. We explore the concept of experience and examine whether it plays a role in addressing the need for transformative learning. Our allies in this task are Oskar Negt from the Frankfurt School tradition, L. A. Paul from a philosophical tradition and René Arcilla. Negt is useful for rethinking the role of experience in pedagogy. Paul helps identify the not-knowing aspect of our current experience and our inability to imagine how decisions translate into one's way of living and being in the world. Arcilla emphasises the importance of keeping conversations going. Jack Mezirow's transformation theory (relying on Habermas) informs the understanding of adult learning and how we can transform our way of being and living while facing experiences of crises and disorientation.
\end{abstract}

Keywords: Crisis, edifying conversation, experience, transformative learning, transformative experience

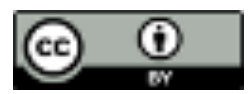




\section{Introduction}

Early in Melville's (1967) Moby Dick, Ishmael looks out over New York Harbour. He meets the moment, and indeed ours, with what he famously calls a 'damp, drizzly November in my soul' (p. 12). Extending his gaze towards the horizon he decides to launch out, to reach beyond the present and see the crisis as a possible new beginning. Ahab, the ship's captain, frighteningly and fearlessly imposes his agenda of revenge and rage on the crew. The hopelessness, the greed, the anger and pain - even the lack of knowledge about what is really happening - are well described by Melville. It is a particularly powerful story as Covid-19, mass migrations, racism and climate change have become current crises. Many are exhausted by the efforts required, and required again and again.

Our current crises are particularly challenging in not-knowing who we are (Eschenbacher \& Fleming, 2020) and what our lives will become following these experiences. Is there a way back or forward? How do we think about a way out? Alanis Morissette (2014) says it best: 'The only way out is through'. If there is a way forward to a new normal, how can this new way of being and living be imagined? Will the experience of crisis lead to transforming who we are and what will be considered important and valued? What will be learnt? Under what circumstances is rational discourse possible?

When lives are lived, individually or collectively, with unproblematic notions of health and safety that become problematic through experiences of crisis, we are confronted with limits to what we thought we control: ourselves and our ways of living. These experiences may provide learning opportunities and call for transformation, 'rethinking deeply held, and often distorted beliefs, about who we are and our lifeworld' (Finnegan, 2019, p. 46).

Limit situations invite us to go beyond, to imagine and learn to identify hidden forces, submerged realities (Moby Dick) and overcome prescribed endings and closed solutions, to imagine, to reflect on present experiences and create breakthrough moments (Greene, 1973) that shatter sedimented thinking and challenge the ability to learn. In the current crisis, we imagine learning as offering transformative possibilities built through transformative conversations (Eschenbacher, 2020) to lift our drizzly Novembers.

What, if anything, can be learnt in a crisis? In a moment of crisis, where one may lose one's way in the world (Arcilla, 1995), where there is a sense of losing direction, there is a strong experienced need to find new directions, ones that may lead out of (or through) current disorientations. We may have lost what is taken for granted, including formerly unproblematic notions of health, freedom of movement, safety or (a sustainable) lifestyle. Crises today have individual, societal and even global dimensions. They leave people experiencing loss struggling to respond to feelings of having lost their way in the world. In needing to engage in a quest for new, transformed (self-)understandings, to find one's way again, and to navigate through crisis, the experience of disrupture provides a fragile ground on which to struggle with formerly unproblematic notions of health and ways of living together. Crises seem to demand action and may require that we shortcircuit reflection, especially critical reflection. The challenge may be to bring about both self-transformation and social change - to think about new thoughts that may unsettle fixed positions personally and socially.

In working towards a critical pedagogy of crisis, it is appropriate to turn for a moment to Jürgen Habermas, on whom Mezirow relied for his critical theory of transformative learning. From his earliest work, Habermas (1954) shifted the traditional Marxist locus of crises from being an inevitable part of our current economic system (capitalism) to understanding capitalism as colonising the state and subverting its ability to bring the 
economy under democratic control. Monetisation of the state and human relations, according to his crisis theory (1983), and the 'dependence of late capitalism on a very weak legitimation basis' have induced crises (1983, p. 38-39). The crises of the economic system lead to political destabilisation (Habermas, 1973, p. 195, 1975), and the 'monetization of the lifeworld' is a current social pathology (1987, p. 332). This encourages a re-think, a redescription, as Rorty calls it (Eschenbacher, 2019; Eschenbacher \& Fleming, 2020) and to acquire new knowledge and new frames of reference that may overcome not-knowing. A crisis suggests a turning point or at least a situation where normal frames of reference are disrupted or do not function as we wish,

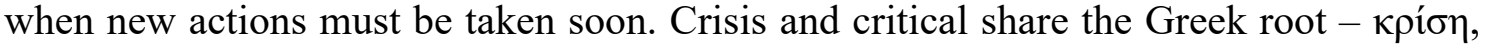
$\kappa \rho i ́ \sigma \iota \mu \eta$, krinein - meaning the ability to discern.

We work towards the conclusion that crisis is best understood when it is both a personal and social experience. To work through (Morissette, 2014) the current situation and search for a critical pedagogy of crisis, we focus on experience as the starting point for learning. This connection with experience is the major ingredient in this search for critical pedagogy. Pedagogy, as used here is not the equivalent to learning. Pedagogy has deep connections with the idea that the theory and practices of education are contested and powerfully influenced by history. In line with Freire, pedagogy captures the notion that teaching and learning are political so that curricula, textbooks, assessments and language used may all empower or disempower learners. Pedagogy refers to the understanding that education is implicated in the ways that power is held and exercised unequally in society. It is easier to associate pedagogy with empowering learners and facilitating active citizens interested in social change and social justice. Experience is a key concept in adult learning theory - in transformation theory, self-directed and experiential learning, andragogy (Irish, 2019) and most crucially in the critical pedagogy of Freire (1972). This paper outlines concepts useful in moving towards a critical pedagogy of crises:

- Adult learning theory built on experience known as Mezirow's transformation theory - informed by the work of Habermas - that is particularly useful for understanding crisis as a motivation for learning and the complexity of thinking required in a new world;

- An exploration of Oskar Negt's concept of experience as dialectical;

- An introduction to the work of Laurie A. Paul on how challenging and difficult it is to imagine the transformed self and life offered by the rational decision-making of Mezirow and Negt;

- Important concepts from René Arcilla on the imperative of continuing conversation in light of the difficulty of imagining transformations when one has lost one's way in the world;

- We conclude with additional brief ideas gleaned by these authors on teaching for a critical pedagogy.

\section{On experience: Negt (and Kluge), Paul, Arcilla and Mezirow}

Oskar Negt (1971) studied philosophy and sociology with Horkheimer and Adorno at the Frankfurt School and is a prominent scholar at Leibniz University Hannover. Experience is central to his pedagogy and he has, with his colleague Alexander Kluge, a lifelong involvement in emancipatory worker education. Stollman (Kluge \& Negt, 2014) writes 
that 'the rallying cry for Negt and Kluge's work is no longer "Workers of the world, unite!" but rather "Experiences of the world, unite!"” (p. 464). We adapt this to our critical pedagogy of crisis: 'Crises of the world, unite!' It is the critical theory inspired by the ideas of Negt on experience and pedagogy that prompt this critical pedagogy.

L.A. Paul (2016) is Professor of Philosophy and Cognitive Science at Yale. She rethinks the idea of undergoing a transformative experience from a philosophical perspective. She provides a different perspective on the experience of crisis and is concerned with decision-making in the light of epistemic gaps, the 'not-knowing' in our current situation (Eschenbacher \& Fleming, 2020). She identifies an inability to imagine how decisions will translate into one's way of being and living in the world. She is a philosopher of experience. We put Paul's (2016) work in conversation with Arcilla (1995) and Mezirow's (1991) version of transformative learning. Though the theory of transformative learning has evolved since Mezirow's version and now includes various possible routes to transformation (Stuckey, Taylor, \& Cranton, 2014), our exploration relies on Mezirow's version.

René Arcilla (1995) is a Professor of Educational Philosophy at New York University with an interest in the philosophy of education, liberal learning, existentialism, and modernism. Asking 'Why Aren't Philosophers and Educators Speaking to Each Other?' (Arcilla, 2002), he makes space for this dialogue. We work with Arcilla's notion of conversational edification, as a means to developing one's selfhood through conversation with others as a practice that is both philosophical and educational. Arcilla's work allows us to build a bridge between these two practices in the face of crisis and disorientation. Conversational edification allows us to enter a conversation where we can seek to understand ourselves and develop selfhood.

Jack Mezirow's (1991) work on transformative learning re-envisions adult learning in the light of crisis and disorientation. His theory of transformation $(1978,2012)$ is concerned with transformative change and has shaped the discourse on adult learning by adding a critical, emancipatory lens. His notion of transformative learning is concerned with developing selfhood and personal growth alongside social action. Mezirow is unwilling to favour one over the other. This tension is inherent in his theory and continues to provokes critique. It is a theory in progress (Mezirow and Associates, 2000).

\section{Oskar Negt: Experience and learning}

Negt works collaboratively with Kluge and his main interests include work as a source of identity and dignity, critical pedagogy for adults and schools, and politics. He (2008) is one of the few critical theorists who explicitly addresses worker (adult) education (Langston, 2020). Negt's traditional Marxist views on the instrumentality of work and the alienation of workers are balanced by an appreciation of the positive role that work plays in social recognition and workers' identities. How workers experience work is his starting point for learning. The experience of workers (learners) (Kluge \& Negt, 2014) is infused with the contradictions and crises of capitalist society and acts as a source of 'resistance to capitalism' (p. 31). His concept of exemplary learning sets out how to work with experience by bringing a sociological imagination to bear to understanding these issues and fostering social action.

Habermas appointed Negt as his assistant at the Frankfurt School in 1962. Habermas identifies new stages of individual and social development that involve new levels of learning. This learning brings new problem situations, risks and burdens. Habermas (1974), in a prescient moment, asserts that: 
as natural scientific medicine brings a few diseases under control, there arises a consciousness of contingency in relation to all illness....Suffering from the contingencies of an uncontrolled process gains a new quality to the extent that we believe ourselves capable of rationally intervening in it. The suffering is then the negative of a new need... (p. 164)

Though we face new crises, the experience of crises is not new. Different places in the world may identify different crises in their regions. Habermas (1995), in a moment of typical idealism, asserts that the world faced the crises of the twentieth century with 'enlightened perplexity' (p. ZB4). However, he soon reverted to a more mundane confidence when he wrote about 'learning from catastrophe?' as part of coping with the damage done to social cohesion by 'dismantling of the welfare state' and 'superpowers gone wild' (Habermas, 2001, p. 47).

The problems, dilemmas, experiences, pain and inability to mourn of many in this Covid era are disorientations and dislocations that may prompt learning. They may also allow us to build a critical understanding of how society is structured and in whose interests it operates in crisis. These experiences of ordinary people form the core concept of Negt's pedagogy. This integrates well with the varying but parallel trajectories of both Habermas and Honneth. All are interested in social justice, reason, truth and democracy. All agree that philosophy aims at the 'practical transformation of the existing social conditions' (Habermas, 1981, p. 469). All offer a vision of the world as it might be. 'Democracy is the only politically conceived social order that has to be learned, over and over, every day, into old age' as a 'process of education and learning' (Kluge \& Negt, 2014, p. 452).

Learning utilises prior experience to construe new or revised interpretations of experience that in turn guide action. Experience may prompt a questioning of what has been taken for granted. As disorienting dilemmas (Mezirow) or perplexity (Dewey, 1966, p. 150; Habermas, 1995, p. ZB4) are the beginning of learning, we suggest that crises today form a motivation for learning. Crises are disorienting dilemmas. As the horizon of meanings available to people may be distorted and the range of meanings available is too often infused with, for example, conspiracy theories and resistance to the knowledge of scientific enquiry, there is a distortion in the lifeworld that complicates thinking through these issues.

The lifeworld is a pool of intuitive knowledge about the objective, social and intersubjective world inhabited by people. It is employed, usually without thinking, to establish and sustain interactions. Habermas (1987, p. 126) considers the knowledge stored in the lifeworld to be deeply sedimented and normally unproblematic in everyday life. However, once the lifeworld becomes problematic, it loses its role as a background certainty. It becomes subject to discursive examination that is a challenge for the ability to critique this shared lifeworld that requires change (1987, p. 126). It seems that the lifeworld is in crisis (Mezirow, 1991, p. 69).

The experience of crisis is not just an individual experience as the 'public domain of the jointly inhabited interior of our lifeworld is at once inside and outside' (Habermas, 2008, p. 14). The inside/outside dichotomy is misleading and even in the most personal moments our consciousness thrives on the 'impulses it receives from the cultural network of public, symbolically expressed, and intersubjectively shared categories, thoughts and meanings' (Habermas, 2008, p. 15). The personal and the lifeworld are dialectically interconnected. It is difficult to imagine a stronger statement than this of the false dichotomy of individual and social, and this idea now informs this pedagogy of crisis. The personal is indeed political; the political is also personal and learning from experience necessarily involves making these connections. Learning requires an ability to perceive 
the world in this connected way. Transformation theory does not have a good record of acknowledging this critical insight (Fleming, 2021). It is this insight (borrowed from Hegel and worked through by Habermas, Honneth and Negt) that, overall, moves this project towards critical pedagogy.

Peter Alheit (2021) provides an example of this connection. Quoting Erving Goffman's 1977 study, he illustrates how gendered social rules influence individual actions and are thus reproduced across generations. According to Goffman, male/female intimate relations are normally of an older/taller man and younger/smaller woman. These are the personal choices of many. These are social and cultural constructs that are difficult to change and that act behind the backs of the people concerned. Here "the "social" breaks into the self-referential self-description of the psychic system, as it were, without being conceptually integrated' (Alheit, 2021, p. 85). The tacit knowledge of how to act as gendered people operates powerfully because it does so precognitively as 'experience knowledge from countless interaction situations and becomes effective to a certain extent in the background' of our actions. It is experienced as beyond question and even natural (Alheit, 2021, p. 86). This tacit knowledge is only available where disruptions occur and where some event forces the participants to reflect. Crises provide such disruptions. This understanding that the lifeworld needs to be transformed is a shorthand way of indicating that questions about whether change is individual or social may miss the point that the answer is yes - both need to be transformed, and a change in either leads to a change in the other.

Negt is under no illusion about the difficulties of such learning in these times and believes that 'the ability of the emancipatory left to effect transformative change is now very low' (Pohl \& Hufer, 2016, p. 206). Kluge's recent book title captures this difficulty and says political and social change is like slow and powerful Drilling through hard boards (Kluge, 2017). Pedagogy in crises is about learning how to think for one's self in a world where fake news, conspiracy theories and rejection of scientific knowledge often dominate and undermine public discourse. This critical pedagogy of crises is an exciting possibility, but Negt is aware that 'drilling through' sounds even more challenging than 'working through'.

Negt offers a new understanding of experience that transcends that of Dewey (Illeris, 2002), for whom experience is firstly in continuity with previous experience. In search of meaning we modify/integrate new experiences with previous experiences. Secondly, experience is created by and in interaction with the broader social environment (Dewey, 1963, p. 43). Learning involves 'that reconstruction or reorganization of experience which adds to the meaning of experience, and which increases ability to direct the course of subsequent experience' (Dewey, 1966, p. 76). The increase in meaning 'corresponds to the increased perception of the connections and continuities of the activities in which we are engaged' (Dewey, 1966, p. 76-77). Learning involves becoming aware of these interactions and continuities.

Relying on Hegel, Negt goes further and asserts that these continuities and interactions are dialectical. This alters our understanding of learning. Learning is not just an adaptation or integration of experience; the process is dialectical. One's individual experience cannot be properly understood unless it is seen as being in a dialectical relationship with broader social conditions alongside one's previous experience. This reframes Honneth's (2014) understanding of how the political and personal are connected. The political is personal, and they are dialectically connected. This reconfiguring of how one's individual problems are dialectically connected with broader social issues is significant. It makes understanding the nature of one's problem or dilemmas and the search for solutions more complex than understood by Mezirow (1991). 
Indeed, without the dialectical dimension, this relationship is misconstrued. The experience of crises is dialectically connected to previous experience. One cannot speak properly of individual experience unless it is connected to broader social issues. It is difficult to speak of crises as individual or social. They are both. To work for the dialectical nature of experience is exactly what Maxine Greene proposed when she wrote about learning how things are connected: 'the self can never be actualized through solely private experiences, no matter how extraordinary these experiences might be' (Greene, 1986, p. 74).

Negt (1971) goes beyond the learning of skills and competences and understands 'workers existence as a social problem' (p. 4). Individual crises are also social problems. His idea of learning involves workers analysing and interpreting their social situation to understand the causes of their current situation and to inform actions to change it. Negt develops a pedagogy of worker education and a teaching manual. His pedagogy (and social theory) is grounded in the experiences of workers.

Negt's pedagogy involves exercising learners' sociological imagination so that both their lived experiences and the possibilities that may emerge are (re)imagined. What he calls exemplary learning is connected to the interests of learners; connects the experiences of learners with broader social issues and is relevant for emancipation (Negt, 1971, p. 97). This is a rare excursion into adult learning theory and practice by a Frankfurt School scholar.

Learning is not just accumulating knowledge; it is a collective journey of selfdetermination that includes taking political and emancipatory actions. Negt supports a curriculum or list of competences that are essential for exemplary learning. The topics taught by Negt (2010) include these six competences: identity competence; historical competence; social justice competence; technological competence; ecological competence and economic competence (p. 218-234). This links learners' individual experiences (of injustices) with broader social issues and explores the interconnections to see how individual experiences and structural issues are connected dialectically. Zeuner (2013) refers to this as meta-learning, and it underpins the six competences (p. 148). Along with dialectical thinking, this is fundamentally important for exemplary learning (Negt, 1993, p. 661). This is also part of the process of our proposed understanding of learning in a critical pedagogy.

A pedagogy of crises involves thinking independently, dialectically, systemically, with sociological imagination, utilising critical reflection and democratic participation. Negt (1973) describes adult learning as an analysis that brings into awareness the historical development of how learners' interests are defined for them and how relationships of power are experienced, such that they can discover through learning the roles they play in society and through study identify options, including actions, that will change their unjust reality. This pushes learning theory into social and political arenas, and this Negt-inspired critical pedagogy of crises provides a framework for an historical and material interpretation of subjectivity as produced by the capitalist system as well as a source for a new social order that will be just and caring (Kluge \& Negt, 2014).

Negt and Kluge (1993) assert that experience is the most important thing that workers actually produce (p. xlviii). Illeris (2002) states this best: 'The working class can break through the distortion of immediate experiences, experience the structural conditions for their experiential development, and then fight to change these conditions' (p. 152). When we understand how experience is influenced by social structures, there is then the possibility of what Maxine Greene (1995) calls breaking-through the inertia of convention when people 'are enabled to explain their "shocks" and reach beyond' (p. 39). Such a pedagogy, Greene continues, 'offers life; it offers hope; it offers the prospect of 
discovery; it offers light' (p. 133). These moments can help transcend limits and engage one's sociological imagination in the process of exemplary learning and social transformation (Negt, 1971; Negt \& Kluge, 1993).

These ideas are not new to adult educators such as Olesen (1989), Wildemeersch (1992) and Illeris (2002). Olesen (1989), quoting Negt, sees 'experience as a collective process because when we experience as individuals we also do so through a socially structured consciousness' (p. 8) or again 'the socialized individual cannot experience individually' (p. 68). The individual is always multiple, or as Brecht calls it, 'the self is always plural' or dividual (cited in Kluge \& Negt, 2014, p. 45). These connections are made to extend the links between the central role of experience in any learning and our critical pedagogy of crises.

Both Negt and Paul place experience at the centre of their work and are concerned with transformation but Paul offers an alternative point of view that allows us to explore more thoroughly the experience of crisis in a learning situation.

\section{L.A. Paul on transformative experience}

We make sense of what life throws at us as we 'shape a coherent meaning out of the raw material of our outer and inner experiencing' (Kegan, 2000, p. 52). We still need to know more about what makes the experience of a crisis a potential prompt for learning. Paul's (2016) work is useful here as she refers to transformative experiences that epistemically and personally alter our meaning making. It is like Kegan's 'metaprocess that affects the very terms of our meaning-constructing' (Kegan, 2000, p. 52). Transformative experiences confront us with the basic unknowability of our subjective futures in a context where new and dramatic changes are emerging, and transformative decision-making draws out the consequences of that epistemic fact. In an important sense, when facing a transformative choice, we lack the knowledge needed to have authority and control over who we will become when choosing how to act (Paul, 2016, p. 110). It seems as if experiences may indeed be transformative and confront us with an unknowability of subjective and collective futures regarding transformative choices. Paul is an important break on the confidence invested in rational thinking through future possibilities, as outlined by Negt (and by Mezirow).

Can we learn from such experiences? They might teach us to humble ourselves, facing the limits of established ways of making decisions for ourselves - individually and collectively - by weighing arguments rationally while being forced to accept an epistemic deficit. The new emerging identity, a consequence of significant change, is not knowable before it emerges. This experience leads us to wonder how to handle crises regarding experiences that may change us, asking, 'Will you be able to recast what life throws, and has thrown, at you in your own terms?' (Arcilla, 1995, p. 99). What does this mean for learners?

Experiences force us to make decisions that we may yet be unable to make. This provides both an opportunity and a necessity to learn transformatively (e.g. Mezirow, 1991, 2012). Is the theory of transformative learning useful for understanding this? Yes and no. Yes, as this theory captures the phenomenon of transformation as adults learn in the light of existential crises and disorienting dilemmas, often in ways that have been unimaginable before. Disorienting dilemmas are crises. No, as this only partly addresses the transformative experiences we are currently facing. It does not adequately answer the question of how to make transformative decisions: In this specific case, we experience a process of transformation that will change us epistemically and personally. It does not 
allow decisions to be made by weighing arguments rationally because of the lack of relevant knowledge available as part of the process of thinking through. How can we choose a future when formerly taken-for-granted ways of being are questioned, and the future remains largely unknown. Paul continues: 'Just at the point where we must decide how to navigate from the present to the future using our first personal perspective, we are confronted by the impossibility of assigning subjective values to future outcomes' (2016, p. 108).

Mezirow's highly rational version of transformative learning promotes discourse based on weighing arguments to make informed decisions. What if we cannot make informed decisions because we simply cannot weigh arguments and assess their viability because it is impossible to know future outcomes?

[T] he problem is that when you face a transformative choice, that is, a choice of whether to undergo an epistemically and personally transformative experience, you cannot rationally make this choice based on what you think the transformative experience will be like. That is, you cannot rationally choose to have the experience, nor can you rationally choose to avoid it, to the extent that your choice is based on your assessments of what the experience would be like and what this would imply about the subjective value of your future lived experience. (Paul, 2016, p. 18-19)

Paul (2016) sharpens our perspective on the limits of (transformative) learning theory facing these kinds of crises:

You can't navigate these decisions by stepping back, rationally evaluating your different subjective possibilities, and then choosing the act that maximizes the expected subjective values of your future lived experience. (...) Instead, you grope forward in deep subjective ignorance of what your future conscious life will be like. (p. 110)

Having to grope forward having lost one's way in the world is of concern. Finding possible ways forward is at the heart of transformative learning theory. It involves challenging and critical questioning and assessing the integrity of deeply held assumptions about how learners 'relate to the world around them' (Mezirow \& Taylor, 2009, p. xi). Mezirow's perspective transformation (Mezirow, 1991) involves doing exactly what Paul (2016) says is impossible: to step back and become aware of formerly unproblematic assumptions that provide grounds for one's way of being and living.

Through engaging in a critical process of reflecting and ultimately changing one's assumptive clusters, adults develop and grow towards a more inclusive and integrative perspective providing grounds for making decisions and living one's life. It can best be described as an 'epiphanic, or apocalyptic, cognitive event - a shift in the tectonic plates of one's assumptive clusters' (Brookfield, 2000, p. 139). An experience of disrupture (Alheit, 2021) is the starting point for learning: 'When our meaning perspectives are questioned, the coherence-producing mechanism of our minds is interrupted (emphasis in original). We are no longer able to interpret the situation based on our previous experiences' (Mälkki, 2019, p. 64). The road to transformation in the light of these disruptive experiences is rational discourse, according to Mezirow (1991), who relies on Habermas (1987) for these ideas. Rational discourse

is that specialized use of dialogue devoted to searching for a common understanding and assessment of the justification of an interpretation or belief. This involves assessing reasons advanced by weighing the supporting evidence and arguments and by examining alternative perspectives. Reflective discourse involves a critical assessment of assumption. (Mezirow, 2012, p. 78) 
Mezirow names several conditions that need to be met to realise discourse, such as accurate and complete information and the ability to weigh evidence objectively. It is exactly these preconditions for discourse that cannot be met, according to Paul, when choices are faced in a crisis.

When one's experience is of having lost one's way and current self-understanding is under question, the need to find oneself and one's way in the world again becomes a major concern. Paul (2016) argues that there are possible ways through:

\footnotetext{
you must choose to have or to avoid transformative experiences based largely on revelation: you decide whether you want to discover how your life will unfold given the new type of experience. If you choose to undergo a transformative experience and its outcomes, you choose the experience for the sake of discovery itself, even if this entails a future that involves stress, suffering, or pain. (p. 129)

Or, in a nutshell, 'the best response to this situation is to choose based on whether we want to discover who we'll become' (Paul, 2016, p. 4).
}

It seems as if answers can be found only after having lived through disruptive experiences. These are what Paul (2016) calls transformative experiences because they are 'both epistemically and personally transformative. Having a transformative experience teaches you something new, something that you could not have known before having the experience, while also changing you as a person' (p. 3).

What would it mean, then, to undergo a transformative experience? You know that 'undergoing the experience will change what it is like for you to live your life, and perhaps even change what it is like to be you, deeply and fundamentally' (Paul, 2016, p. 3). Learning, especially learning with a promised deadly outcome (as Paul calls it), is risky, and outcomes are not guaranteed. The key to our critical pedagogy of crisis is the experience of crisis itself and how it is worked through by learners. Knowing what we now know, one wonders why anyone will start a transformative journey.

\section{René V. Arcilla on making the conversations last}

In searching for a more satisfying answer, we turn to René V. Arcilla (1995) who articulates how edifying conversations (Rorty) can be undertaken that are rational, aim at self-understanding and build on experience. Transformative learning offers another dimension to this process, where the learner's way of being and knowing, 'the form itself [is] at risk of change (and not just change but increased capacity)' (Kegan, 2000, p. 49). We recall the previous discussion prompted by Alheit and Goffman, where self is not an isolated (from the social context) entity. This idea of self-formation remains central when 'we choose to become the kind of person - without knowing what that will be like - that these experiences will make us into' (Paul, 2016, p. 123). It allows us to take responsibility for our own learning, essentially owning it. Only by owning it, we can recast what life presents and has thrown at us (Arcilla, 1995). This kind of learning is multi-layered; it holds the tension between being dangerous, terrifying and liberating at the same time. Radical questioning, according to Bernstein (2016), may be

terrifying because it means giving up the familiar banisters and guidelines that we normally accept in orienting our lives; dangerous because, when such questioning is truly radical, it seems to leave us with nothing; liberating (emphases in original) because it frees us from illusions and enables us to confront our subjectivity and inwardness without illusions. (p. 121) 
Why and when would it make sense to engage in this kind of (learning) process? What opportunities do transformative choices hold? Why should one learn transformatively, having already lost one's way in the world? Arcilla (1995) responds: 'What motivates your efforts to learn is the desire for self-knowledge. Yet what if the others to whom you turn have no way of directly revealing you to yourself; what if they are equally searching for themselves?' (p. 6). Bernstein's nothing becomes something through the process of discovering who we will become, as a possibility and necessity of learning.

Transformative experiences provide us with opportunities to understand that 'the various self-conceptions you take for granted do not form a coherent whole' (Arcilla, 1995, p. 6). They provide the fragile ground for searching for a new (self-)understanding. As we have seen earlier, Covid-19, systematic racism and violence alongside climate change hold two dimensions at their heart: an individual and a societal, global dimension. All of these crises, as different as they might be in different places, reflect what Mezirow (1978) describes as distinctive elements and prerequisites for a transformation learner who 'comes to identify her personal problem as a common one and a public issue' (p. 15). It is this connection that allows the learner to progress and bridge the divide between individual and social learning. Personal projects of self-actualisation and development as well as social action are possible outcomes of Mezirow's transformative learning. To categorise issues as either individual or social and to see learning as also divided in this way may be a false dichotomy. The desire to return to normal, as many desire in the present crisis, may hinder or foreclose transformative change.

When transformative learning theory places such an emphasis on rational discourse, as Mezirow did, we ask, where can we go from here? Can Mezirow's notion of rational discourse be sustained when, as we have just seen, it lacks important features that would provide the kind of context for engaging in a constructive way with transformative experiences and decisions? Mezirow's theory already omits the dialectic nature of experience. We might also have to add another dimension to transformative learning. It needs a different kind of dialogue, one that is less concerned with exchanging arguments and dedicated to providing a safe (enough) space for adults to struggle constructively with transformative experiences. If we cannot engage in a dialogue that requires us to step back from our experiences and weigh arguments about how to proceed from where we are, we need to extend transformative learning theory as we presently know it.

We suggest adding a different kind of dialogue, one that has been introduced as transformative conversation (Eschenbacher, 2020). It holds many of the same features as Arcilla's (1995) notion of edifying conversation and adds a transformative dimension to it. Instead of attempting to arrive at a tentative consensus, as Mezirow $(1991,2012)$ suggests through rational discourse, Arcilla proposes a different pathway, highlighting a different, important dimension. As adults are in need of

each other to help them rediscover a sense of self-direction which they must nevertheless claim for themselves. Hence they have recourse to conversation, to an exploratory, associative, open-ended, tolerant exchange of intimations free from the demand that it issue in conclusions binding on all. (Arcilla, 1995, p. 7)

The idea of edification is closely tied to autobiography and becomes especially helpful for individuals struggling with the kinds of transformative decisions that force them to choose whether they want to discover who they will become after the transformative experience.

Arcilla's (1995) notion of edifying conversation seems to address many of the requirements for making these transformative choices: 'As we edify ourselves in response to events that befall us (...) we develop our ability to weave contingent but consistent 
stories of the course of our own lives' (Arcilla, 1995, p. 100). Arcilla (1995) continues: 'the hope of agreement is never lost as long as the conversation lasts' (p. 74). Moreover, following Rorty's conversational conception of reason, Arcilla outlines more interesting and productive ways of speaking about ourselves. The task of reasonable conversations is to edify ourselves - to have conversational edification. It may be that Arcilla, in a way that is profoundly significant for this fragmented moment in history, has argued successfully for an anti-antagonistic conversation adding to his Rorty-inspired edifying conversation.

Translating his idea of edifying conversation into the debate about transformative learning (Eschenbacher, 2020) leaves us with a new direction for the theory itself. This provides sufficient space for a Habermasian notion of discourse where we have access to necessary information and possible outcomes, as well as a notion of transformative conversations where we lack epistemic access and cannot perceive possible outcomes, as the future remains unknown. Building on our own common vulnerabilities and the many things about which we are unsure (especially in a crisis), we can take the risky step of leaving home and experiencing how 'we are all strangers to ourselves, together cast into an unfamiliar unheimlich home' (p. 151). The concept of transformative edifications we suggest is redefined as transformative conversations (Eschenbacher, 2020).

\section{Implications for teaching a critical pedagogy of crises}

Previously, we identified some implications for teaching, as it is a challenge to discuss pedagogy without discussing teaching. According to Negt, a curriculum of competencies and exemplary learning are practical ways in which a pedagogy of crises may be made real in learning environments. Negt (and Kluge) systematically present materials and suggestions as to how their ideas might be utilised in learning situations (Kluge \& Negt, 2014; Negt \& Kluge, 1993). They use science fiction and a range of innovative materials to support and enhance the critical intelligence of learners (Negt \& Kluge, 1993, p. 106). Negt's contribution to understanding adult learning also includes the concepts of exemplary learning and societal competencies. Negt (1971) builds on the interdisciplinary method of C. Wright Mills that illuminates 'structural relationships between individual life histories, immediate interests, wishes, hopes and historical events' (p. 28). As we navigate crises, these connections are the connective tissue of learning.

When learning is discussed in times of crisis, whether thinking of struggling with a global pandemic, racism or climate change, we benefit from extending transformative learning by adding this further conversational format. In edifying conversations, learners can engage as fellow conversationalists 'in questioning themselves before taking things for granted, in order to receive their being at a loss as a present' (Arcilla, 1995, p. 2). It is an attitude that invites adult learners to adopt a certain attitude, one where answers about how to best tackle transformative experiences can remain unknown and outcomes remain unclear. It also allows us - pushing our idea through - to choose that we want to discover the adult learners we will become by undergoing transformative experiences.

All the allies in this exploration are interested in pedagogy and the implications of their ideas for teaching. Using science fiction, satire, fragments of literature, film and documentaries Negt alongside Paul encourages dangerous thoughts of critical intelligence. Kluge and Negt (2014) collect a visual archive of pedagogical methods for facilitating the exploration of how things could be different (p. 260). Kluge's book title names this pedagogy: Learning processes with a deadly outcome (Kluge, 1996). In this way, they are remarkably in step with previous Frankfurt School members and yet 
surprisingly different too. Paul (2016, p. 1), for example, adds an imaginative pedagogy when she asks her readers to 'imagine becoming a vampire' as her introduction to her study of transformative experiences. Her methodology is every bit as unusual as Negt and Kluge.

Arcilla's (1995) notion of (liberal) learning is inspired by several aspects Oakeshott (1989, p. 41) identified as distinctive, as an 'invitation to disentangle oneself, for a time, from the urgencies of the here and now and to listen to the conversation in which human beings forever seek to understand themselves'. Arcilla (1995) suggests joining the conversation instead of just listening to it. But what is it that makes the idea to join so attractive? It 'is the recognition that your sense of yourself leaves something to be desired' (Arcilla, 1995, p. 3) - especially in times of crisis and disorientation.

\section{Conclusion}

A critical pedagogy of crises continues to evolve as does the task of making further links and connections, whether through Negt, Paul, Arcilla or others, so that a fuller and more satisfying iteration of a theory of learning might unfold to meet the increasingly challenging learning dilemmas faced by individuals, communities and society. There is urgency in the task and risk. It may be that not-knowing becomes the new normal, and the pursuit of rational certainty emerging from rational discourse or conversations may not be entirely possible.

As rational conversations are the domain of critical theory (Habermas) and transformative learning (Mezirow), one may also have to attend to the challenges of this pedagogic task. In addition, as experience is the ground on which learning theory builds, there is another challenge that involves understanding that experience is a more fertile basis for learning. The dialectical nature of experience allows us to view a current emphasis on subjectivity as in need of further elaboration. The philosophical objections of Paul or the power of continuing transformative conversations of Arcilla may provide ideas that could sustain learning in crises that are not just ahead but already part of our experience. This is the state of this search that is attempting to move towards a critical pedagogy of crises.

It may be the case that we can imagine ourselves (metaphorically) standing on the Pequod in Moby Dick. In that moment, like the crew, we know very little. We gather what knowledge and learning we can and together process it with edifying conversations as much as with rational discourse so that together social action, real change, and real transformations are not only possible but pursued relentlessly but with anti-antagonistic solidarity. What can be offered in contrast to this solidarity? We do know that Ahab alone can do nothing, or very little.

Ishmael in Moby Dick spends a night sharing a bed with Queequeg, a cannibal (p. 28), but in the morning, following their conversations, he thinks this man is "worth unusual regarding' (p. 34). When a short while later Queequeg is prevented from boarding the ship because he is not a Christian, Ishmael speaks on his behalf saying he is a Christian and belongs to the same Church 'to which you and I, ... and all of us, and every mother's son and soul of us belong; the great and everlasting First Congregation of this whole worshipping world; we all belong to that;... in that we all join hands'(p. 83).

It may be a shared humanity and solidarity that will be the basis for working through our current existential crises; however, they are named and experienced. In the end, Ishmael is in an untenable position, left alone, the only survivor of the entire adventure. He alone survives to tell the terrible and tragic tale. A lone survivor is not tenable. Or, in 
the words of Kurantowicz, Olesen and Wildemeersch (2014), 'a human being is a human being is a human being is a human being' (p. 145).

\section{References}

Alheit, P. (2021). Biographicity as 'mental grammar' of postmodern life. European Journal for Research on the Education and Learning of Adults, 12(1), 81-94.

Arcilla, R. V. (1995). For the love of perfection: Richard Rorty and liberal education. New York: Routledge.

Arcilla, R. V. (2002). Why aren't philosophers and educators speaking to each other? Educational Theory, $52(1), 1-11$.

Bernstein, R. J. (2016). Ironic life. Malden: Polity Press.

Brookfield, S. D. (2000). Transformative learning as ideology critique. In J. Mezirow (Ed.), Learning as transformation: Critical perspectives on a theory in progress (pp. 125-148). San Francisco, CA: Jossey-Bass.

Dewey, J. (1963). Experience and education. New York: Macmillan.

Dewey, J. (1966). Democracy and education. New York: The Free Press.

Eschenbacher, S. (2019). Drawing lines and crossing borders: Transformation theory and Richard Rorty's philosophy. Journal of Transformative Education, 17(3), 251-268.

Eschenbacher, S. (2020). Transformative learning theory and migration: Having transformative and edifying conversations. The European Journal for Research on the Education and Learning of Adults, 11(3), 367-381.

Eschenbacher, S., \& Fleming, T. (2020). Transformative dimensions of lifelong learning: Mezirow, Rorty and Covid-19. International Review of Education: Journal of Lifelong Learning, 66(5), 657-672.

Finnegan, F. (2019). 'Freedom is a very fine thing': Individual and collective forms of emancipation in transformative learning. In T. Fleming, A. Kokkos, \& F. Finnegan (Eds.), European perspectives on transformation theory (pp. 43-57). London: Palgrave Macmillan.

Fleming, T. (2021). Toward a critical theory of transformative learning: Learning from Oskar Negt. International Journal of Adult Education and Technology, 12(1), 1-16.

Freire, P. (1972). Pedagogy of the oppressed. London: Penguin.

Goffman, E. (1977). The arrangement between the sexes. Theory and Society, 4, 301-331.

Greene, M. (1973). Teacher as stranger: Educational philosophy for the modern age. Belmont, CA: Wadsworth.

Greene, M. (1986). Reflection and passion in teaching. Journal of Curriculum and Supervision, 2(1), 6881.

Greene, M. (1995) Releasing the imagination: Essays on education, the arts and social change. San Francisco, CA: Jossey-Bass.

Habermas, J. (1954). Die Dialektik der Rationalisierung Von Pauperismus in Produ Ktion und Konsum [Rationalization of poverty in production and consumption]. Merkut, 78, 701-723.

Habermas, J. (1973). Theory and practice. Boston, MA: Beacon Press.

Habermas, J. (1974). Toward a reconstruction of historical materialism. In J. Habermas, Communication and the evolution of society (pp. 130-177). Boston, MA: Beacon Press.

Habermas, J. (1975). Legitimation crisis. Boston, MA: Beacon Press.

Habermas, J. (1981). Kleine Politische schriften I-IV [Short political writings]. Frankfurt-am-Main: Suhrkamp.

Habermas, J. (1983). Some conditions for revolutionizing late capitalist societies. Canadian Journal of Political and Social Theory, 7(1-2), 32-42.

Habermas, J. (1987). The theory of communicative action. Vol. 2. Boston, MA: Beacon Press.

Habermas, J. (1995, December 30) Aufgeklärte Ratlosigkeit. Warum die Politik ohne Perspektiven ist [Enlightened perplexity: Why politics has no prospects]. Frankfurter Rundschau, p. ZB4.

Habermas, J. (2001). Learning from catastrophe? In J. Habermas, The postnational constellation (pp. 3857). Cambridge: Polity.

Habermas, J. (2008). Between naturalism and religion. Cambridge: Polity.

Honneth, A. (2014). The I in we: Studies in the theory of recognition. Cambridge: Polity.

Illeris, K. (2002). The three dimensions of learning: Contemporary learning theory in the tension field between the cognitive, the emotional and the social. Malabar, FL: Krieger.

Irish, K. (2019). What is adult learning theory and why is it important? Retrieved March 17, 2021 from https://www.ej4.com/blog/what-is-adult-learning-theory-and-why-is-it-important 
Kegan, R. (2000). What 'form' transforms? A constructive-developmental approach to transformative learning. In J. Mezirow (Ed.), Learning as transformation: Critical perspectives on a theory in progress (pp. 35-69). San Francisco, CA: Jossey-Bass.

Kluge, A. (1996). Learning processes with a deadly outcome. Durham, NC: Duke University Press.

Kluge, A. (2017). Drilling through hard boards: 133 Political stories. Chicago, IL: University of Chicago Press.

Kluge, A., \& Negt, O. (2014). History and obstinacy. New York: Zone Books.

Kurantowicz, E., Olesen, H.S., \& Wildemeersch, D. (2014). A human being is a human being is a human being is a human being: The issue of migration in Europe and the responses of adult education. The European Journal for Research on the Education and Learning of Adults, 5(2), 145-148.

Langston, R. (2020). Dark matter: A guide to Alexander Kluge and Oskar Negt. London: Verso.

Mälkki, K. (2019). Coming to grips with edge-emotions: The gateway to critical reflection and transformative learning. In T. Fleming, A. Kokkos, \& F. Finnegan (Eds.), European perspectives on transformation theory (pp. 59-73). London: Palgrave Macmillan.

Melville, H. (1967). Moby Dick. New York: W.W. Norton.

Mezirow, J. (1978). Perspective transformation. Adult Education Quarterly, 28(2), 100-110.

Mezirow, J. (1991). Transformative dimensions of adult learning. San Francisco: JosseyBass.

Mezirow, J. (2012). Learning to think like an adult. Core concepts of transformation theory. In E.W. Taylor, \& P. Cranton (Eds.), The handbook of transformative learning: Theory, research, and practice (pp. 73-95). San Francisco, CA: Jossey-Bass.

Mezirow, J. \& Associates (2000). Learning as transformation. Critical perspectives on a theory in progress. San Francisco, CA: Jossey-Bass.

Mezirow, J., \& Taylor, E. W. (2009). Preface. In J. Mezirow, \& E. W. Taylor (Eds.), Transformative learning in practice: Insights from community, workplace, and higher education (pp. xi-xiv). San Francisco, CA: Jossey-Bass.

Morissette, A. (2014). Out is through. Retrieved October 1, 2020 from https://www.youtube.com/watch?v=tE28ahYAOk8

Negt, O. (1971). Soziologische Phantasie and exemplarisches Lernen: Zur Theorie und Praxis der Arbeiterbildung, [Sociological imagination and exemplary learning: On the theory and practice of workers' education]. Hamburg: Europäische Verlagsanstalt.

Negt, O. (Winter, 1973). Don't go by numbers, organize according to interests!: Current questions of organisation. New German Critique, 1, 42-51.

Negt, O. (1993). Wir brauchen ein zweite, gesamtdeutsche Bildungsreform [We need a civic all-German educational reform]. Gewerkschaftliche Monatshefte, 11, 657-666.

Negt, O. (2008). Adult education and European identity. Policy Futures in Education, 6(6), 744-756.

Negt, O. (2010). Der politische Mensch: Demokratie als Lebensform [The political person: democracy as a way of life]. Göttingen: Steidl Verlag.

Negt, O., \& Kluge, A. (1993). Public sphere and experience: Analysis of the bourgeois and proletarian public sphere. Minneapolis, MN: University of Minnesota Press.

Oakeshott, M. (1989). A place of learning. In T. Fuller (Ed.), The voice of liberal learning: Michael Oakeshott on education (pp. 17-42). New Haven, CT: Yale University Press.

Olesen, H.S. (1989). Adult education and everyday life. Roskilde: Adult Education Research Group.

Paul, L. A. (2016). Transformative experience. Oxford: Oxford University Press.

Pohl, K., \& Hufer, K-P. (2016). An interview with Oskar Negt - 2004. International Labour and Working-Class History, 90, 203-207.

Stuckey, H. L., Taylor, E. W., \& Cranton, P. (2014). Developing a survey of transformative learning outcomes and processes based on theoretical principles, Journal of Transformative Education, 11(4), 211-228.

Wildemeersch, D. (1992). Ambiguities of experiential learning and critical pedagogy. In D. Wildemeersch, \& T. Jansen, (Eds.), Adult education, experiential learning and social change: The postmodern challenge. Roskilde: Roskilde University Press.

Zeuner, C. (2013). From workers education to societal competencies: Approaches to critical emancipatory education for democracy. European Journal for Research on the Education and Learning of Adults, 4(2) 139-152. 